\title{
Particulele afirmative în limba română - perspectivă diacronică și areală
}

\author{
Affirmative particles in Romanian - diachronic \\ and areal perspective
}

\author{
Tomasz Klimkowski \\ Uniwersytet im. Adama Mickiewicza w Poznaniu \\ tomasz.klimkowski@amu.edu.p1
}

\begin{abstract}
The present article analyses the Romanian affirmative particles from a diachronic and areal perspective in order to determine their origin. The analysis of a corpus of original literary texts and translations of religious texts as well as dictionaries and grammars from different epochs has resulted in distinguishing in Romanian the following affirmative particles: aşa (since the $16^{\text {th }}$, and especially the $17^{\text {th }}$ century), $e i$ (in the $16^{\text {th }}$ century), ie (since the second half of the $18^{\text {th }}$ century) and $d a$ (since the $19^{\text {th }}$ century). As the last three can be put in the East European areal context, a natural explanation of their origin would be the assumption that they were borrowed respectively from Church Slavonic, German and Slavic. However, also because of the special status of affirmative particles as a part of basic vocabulary of most languages, we propose to apply to them the foothold theory inspired by Abraham's half-open doors theory (2011). Accordingly, we believe that borrowing the particle ei from Church Slavonic could have used as a foothold the Old Romanian conjunction $e(<$ lat. et) and the ie borrowed from German was superposed on the Romanian verbal form $e$ 'is'. On the other hand, the Slavic loanword $d a$ coincided with the inner semantic evolution of the Romanian forms dară $\sim d a r \sim d a$ from an adversative conjunction to an affirmative particle.
\end{abstract}

Keywords: affirmative particles, diachronic linguistics, areal linguistics, etymology of the Romanian $d a$, half-open doors theory, foothold theory 


\section{INTRODUCERE}

În general, există două tipuri de răspuns la o întrebare închisă (yes-no question): reluarea unei părți din întrebare (de obicei, a verbului la o formă finită, cu sau fără negație) și folosirea unor cuvinte specializate, afirmative sau negative (Holmberg, 2015). Lingvistica românească tradițională (la fel ca și cea franceză și engleză) clasifică formele de acest tip drept adverbe. În schimb, în lingvistica germană și slavă, acestea sunt denumite, de cele mai multe ori, particule. În tradiția gramaticală românească, termenul particulă desemnează mai degrabă un element de întărire ataşat unui cuvânt (fiind numit și particulă deictică) (DSL, 1997, p. 355; ELR, 2001, pp. 419-421). Totuși, este folosit uneori termenul particulă adverbială sau adverb-particulă, echivalent cu cel de semiadverb (DSL, 1997, p. 355; ELR, 2001, pp. 419-421). Astfel, conform unor definiții ale termenului particulă (MDA, 2010, II, p. 276), acesta constituie un termen generic pentru cuvinte cu corp fonetic redus, mai ales pentru părțile de vorbire neflexibile, printre care se numără și adverbele de afirmație. Așadar, indiferent de dificultatea delimitării particulelor de alte clase și, în special, de adverbe, vom folosi în continuare termenul particulă afirmativă, având în vedere valoarea specială a unor astfel forme; de altfel, el apare, de asemenea, la Mihăilă (1960) și Niculescu (1961) (în alternanță cu termenul adverb afirmativ). Spre deosebire de adverbele propriu-zise, care completează verbul, cuvântul afirmativ reprezintă un răspuns pozitiv la o întrebare, înlocuind propoziția întreagă sau o parte a acesteia, care devin atunci eliptice, iar dacă se reactualizează în discurs, devin o apoziţie a afirmației, cf. (1a) vs. (2a) și (1b) vs. (2b).

(1)

a. Vii mâine?

b. Vii mâine?

(2)

a. $D a[$, vin [mâine $]$.

b. $D a[$, mâine $]$.

De aceea, asemenea cuvinte au mai fost clasificate ca interjecții gramaticale, deoarece sunt capabile de relații sintactice foarte limitate, sau ca o „clasă” aparte; în lingvistica actuală se vorbește - în franceză, engleză, italiană etc. - mai ales de prophrase, pro-sentence, pro-frase, ca, de exemplu, într-o sintaxă a limbii române vechi în limba engleză (Pană Dindelegan, 2016), în care, totuși, se menționează the negative pro-sentence, dar nu și the affirmative pro-sentence. Termenul a intrat în română ca profrază ; cu privire la $d a$, este folosit, printre altele, în GALR (2008, II, p. 672 și urm.) și GBLR (2010, p. 306). În același timp, în GALR, se discută (în general) proformele (2008, I, pp. 57-58).

Articolul de față își propune să analizeze problema particulelor / profrazelor afirmative românești din două perspective: diacronică și areală. Scopul principal pe 
care îl urmăresc descrierea și analiza faptelor lingvistice din aceste perspective este cel de a explica originea particulelor în cauză, prin revizuirea unor ipoteze anterioare și propunerea unei soluții noi. Situația din română reprezintă o ilustrare a tendințelor generale în acest sens și, raportată la alte cazuri (în special, la situaţia lingvistică din Europa de est), permite formularea unor concluzii cu privire la statutul particulelor afirmative și problema împrumutării lor.

Originea particulelor afirmative din limba română și, în special, a particulei $d a$, face obiectul unor studii detaliate semnate de Niculescu (1961) și Massey (2008), găsindu-și loc, de asemenea, în monografia despre slavisme a lui Mihăilă (1960) sau în gramatica limbii române vechi a lui Frâncu (2009). Într-o anumită măsură, ea este discutată și în sinteze precum Pușcariu (1940) și Rosetti (1986), dar, mai ales, în dicționarele etimologice: DEDR (1879), DER (2002), DEM (1978) şi în cele explicative, care indică, de obicei, etimologia cuvintelor-titlu din corpul lor.

În acest articol, descrierea diacronică este bazată, în primul rând, pe analiza datelor lingvistice furnizate de un corpus de texte din perioada limbii române vechi și moderne. Dintre corpusurile elaborate până acum, am folosit CETRV (textele din 1521-1640) și ROMTEXT. Separat, au fost analizate o serie de texte literare: originale și traduse, inclusiv traduceri biblice, care acoperă într-un mod aproape neîntrerupt toată istoria limbii române scrise, permițând, astfel, urmărirea evoluției diferitelor fenomene lingvistice, inclusiv a modalităților de exprimare a afirmației ${ }^{1}$. Alte repere importante sunt constituite de lucrări de referință precum dicționare, gramatici și manuale din secolele XVIII-XIX, care consemnează uzul din epoca respectivă ${ }^{2}$.

Perspectiva areală a fost obținută prin raportarea particulelor afirmative românești identificate pe plan diacronic la contextul areal, adică la contactul lingvistic al limbii române cu spaţiul central-european și, mai ales, cu cel slav de sud-est și de est. La nivel teoretic, în cadrul abordării areale, aplicăm elemente ale metodologiei elaborate de Swadesh (1952, 1971), precum lista cuvintelor de bază considerate ca fiind cele mai rezistente la schimbare și, prin urmare, la înlocuirea lor prin împrumuturi din alte limbi.

Reunind cele două perspective, pentru a stabili originea formelor analizate, recurgem la concepte specifice precum: teoria „ușilor întredeschise” ca mecanism de schimbare lingvistică (Abraham, 2011), adoptată într-o variantă proprie cu o modificare la nivel de formulare, ca teorie a ,punctelor de sprijin”, și evoluţia fonetică neregulată datorată frecvenței (Mańczak, 1971).

\footnotetext{
${ }^{1}$ În acest scop, am ales cele mai importante traduceri românești ale textului biblic care au în cuprinsul lor Noul Testament sau cel puțin o parte din acesta și am identificat în ele o serie de pasaje care conțin formule afirmative. Pe de altă parte, rezultatele analizei corpusului de traduceri biblice trebuie tratate cu prudență, limbajul biblic manifestând o puternică tendință conservatoare și chiar arhaizantă.

${ }^{2}$ Chiar dacă, uneori, este reflectat nu atât uzul real, ci cel dorit de autor, mai ales în cazul reprezentanţilor curentelor latiniste.
} 


\section{PERSPECTIVA DIACRONICĂ}

\subsection{Româna veche (1521-1780)}

În latină clasică, afirmația se exprima prin reluarea integrală sau parțială a întrebării și, mai ales, a verbului (cu modificări necesare). În afară de aceasta, o afirmație generalizată putea fi exprimată prin ita, sau alte adverbe precum etiam, utique, omnino, immo sau sic, cel din urmă generalizându-se în latina târzie și stând la baza particulelor afirmative din majoritatea limbilor romanice (italiană, spaniolă, portugheză etc.).

Tabelul 1. Exprimarea afirmației în traduceri biblice românești (până în 1780)

\begin{tabular}{|c|c|c|c|c|c|c|c|}
\hline & Mt 9, 28 & Mt 11, 26 & Mt 13, 51 & Mt 15, 27 & Mc 7, 28 & In 11,27 & In 21,15 \\
\hline gr. & vaí & vaí & vaí & voí & $\mathrm{X}$ & vaí & vaí \\
\hline lat. & utique & ita & etiam & etiam & utique & utique & etiam \\
\hline slav. & Eй & Eй & Eй & Ей & Eй & Ей & Ей \\
\hline ES, 1551-53 & ei & ei & ei & aşa-i & $\mathrm{X}$ & $\mathrm{X}$ & $X$ \\
\hline TC, 1560-61 & ei & ei & ei & ei & ei & adevăr & adevăr \\
\hline NTB, 1648 & [creadem] & bine- $\mathrm{i}$ & [înțeleagem] & aşia-i & aşia e & [crez] & aşa \\
\hline BBuc. 1688 & aşa & așa & așa & aşea & aşa & aşa & așa \\
\hline BVBI, 1760-61 & aşea e & așa & adevărat & aşa e & adevărat & adevărat & așea e \\
\hline
\end{tabular}

\begin{tabular}{|c|c|c|c|c|c|c|c|}
\hline & FA 5,8 & FA 22,27 & $\operatorname{Rm~3,29}$ & Flm 1, 20 & Ap 14, 13 & Ap 16, 7 & Ap 22, 20 \\
\hline gr. & vaí & vaí & vaí & vaí & $v \alpha i ́$ & vaí & vaí \\
\hline lat. & etiam & etiam & immo & ita & amodo iam & etiam & etiam \\
\hline slav. & Ей & Ей & Ей & Ей & EЙ & EЙ & EЙ \\
\hline CB, 1559-60 & ee & $\mathrm{X}$ & $X$ & $X$ & $\mathrm{X}$ & $\mathrm{X}$ & $\mathrm{X}$ \\
\hline AC, 1563-66 & adevăr & ei & adevăr & $\mathrm{X}$ & $\mathrm{X}$ & $X$ & $\mathrm{X}$ \\
\hline CV, 1563-83 & $\mathrm{X}$ & ee & $X$ & $X$ & $\mathrm{X}$ & $\mathrm{X}$ & $\mathrm{X}$ \\
\hline NTB, 1648 & aşa & aşia iaste & adevăr & aşa & aşia-i & aşia-i & aşia-i \\
\hline BBuc, 1688 & aşa & aşa & $\mathrm{ba}$ & aşa & aşa & aşa & aşa \\
\hline BVBI, 1760-61 & $\mathrm{X}$ & $\mathrm{X}$ & $\mathrm{X}$ & $\mathrm{X}$ & $\mathrm{X}$ & $\mathrm{X}$ & $\mathrm{X}$ \\
\hline
\end{tabular}

Din cauza unui număr mic și a unui volum redus și, de asemenea, a tipului lor (documente juridice, scrisori), textele românești din secolul al XVI-lea din categoria celor originale (netraduse) nu oferă date lingvistice necesare cercetării noastre. Textele literare originale din secolele XVII-XVIII, reprezentate, în primul rând, de cronicile muntenești și moldovenești, precum și de singura operă literară originală propriu-zisă a epocii (Istoria ieroglifică de Cantemir, 1705), formează un corpus 
mult mai vast decât cele din secolul precedent. $\mathrm{Cu}$ toate acestea, din cauza structurii lor preponderent narative, cu puține dialoguri și elemente de discurs indirect, nu am identificat acolo elemente afirmative propriu-zise. Așadar, referitor la limba română veche, având în vedere specificul ei rezultat din contextul cultural al epocii, ne vom limita la analiza unui corpus de texte religioase (tabelul 1).

Cea mai veche modalitate de exprimare a afirmației din română trebuie să fi fost reluarea elementului din propoziție care reprezintă obiectul întrebării (3). De asemenea, afirmația putea fi exprimată prin formule universale reprezentate de un adverb modal sau o locuțiune adverbială, însoțite uneori de un verb. În secolul al XVI-lea, un astfel de adverb este adevăr $^{3}$, folosit mai ales în tipăriturile lui Coresi $(4 a, b)$. Pe lângă aceasta, este atestată deja folosirea cu sens afirmativ a adverbului modal aşa. În ES (1551-53), pe lângă perifraza aşa-i (5a), care, ca expresie, echivalează cu o afirmație, este ocurentă, de asemenea, utilizarea lui aşa fără suport verbal (5b).

(3) Intrebare: „Creștin ești? ” Răspuns: „Creștin” (CC, 1559-64, p. 5).

(4)

a. „Ei credința aceasta?”. Grăi lui: „Adevăr, Doamne” (TC, 1560-61) (In 11, 26-27).

b. ,Spune-mi s-aţi dat satul într-atîta?” Ia zise: „Adevăr, într-atîta” (AC, 1563-66) (FA 5, 8).

(5)

a. Iară ia dzise: „Așa-i, Domne, ce șă cînii mănîncă de forime ce cad de la masa dom‘nu>-seu” (ES, 1551-53) (Mt 15, 27).

b. Sau prentru ce ați mărs a vedea? Proroc? Așa greiesc voo, că-i mai mare de proroc (ES, 1551-53) (Mt 11,9).

Dacă în secolul al XVI-lea se poate vorbi deja despre o particulă afirmativă generalizată, aceasta era, în primul rând, forma ei, cu o folosire destul de regulată, cel puțin în textele traduse, cf. ES (1551-53) (6a) și tipăriturile coresiene: TC (156061) (6b) sau AC (1563-66) (6c). În CB (1559-60) și CV (1563-83), se folosește forma ee, care, conform lui Frâncu (2009, p. 405) și MDA (2010, I, p. 789, 793), reprezintă o variantă a lui ei. A se compara, în acest sens, alternanța dintre ei și ee din versiunile diferite ale Apostolului, cf. AC (1563-66) (6c) și CV (1563-83) (7).

(6)

a. șă grei lor: „Au credeți că poci aceste face?” Greiră lui: „Ei, Domne!” (ES, 1551-53) (Mt 9, 28).

b. și grăi lor Isus: Creadeţi că pociu aceasta face?”. Grăiră lui: „Ei, Doamne!” (TC, 1560-61) (Mt 9, 28).

\footnotetext{
${ }^{3}$ Din punct de vedere etimologic, adevăr reprezintă un adverb (< lat. *ad de verum). Cu timpul, devine un substantiv și, pentru a avea valoarea adverbială inițială, trebuie folosit sub forma intr-adevăr sau în adevăr.
} 
c. Apropie-se miiariul, zise lui: „Grăiaște-mi, să ești rimleanin?” El zise: „Ei” (AC, 1563-66) (FA 22, 27-28).

(7) Deaci se apropie miiaşul şi lu întrebă, dzise: „Spunre-mi se rrimleanu eşti”. Elu dzise: ,Ee !” (CV, 1563-83) (FA 22, 27-28).

Să observăm că, în pasajele din TC (1560-61) care conțin un cuvânt afirmativ (redat întotdeauna, în varianta slavonă, ca Eй), în primele două Evanghelii (după Matei și Marcu), nu se folosește decât ei $(6 \mathrm{~b})$, pe când în celelalte (după Luca și Ioan), apare doar adevăr (4a). E posibil, deci, ca textele care fac parte din această tipăritură să fie traduse de (cel puțin) doi traducători, cu opțiuni diferite de redare a afirmativului Eй din textul slavon.

Deși statutul ei de particulă specializată cu sens afirmativ nu ridică îndoieli (spre deosebire de adevăr, nu este atestată cu alte sensuri și funcții), forma ei/ee apare, de fapt, doar în traduceri. Nu se știe în ce măsură se folosea în limba vorbită de atunci, dar s-ar putea să fi avut o anumită circulaţie măcar la nivel cult, dat fiind faptul că, în secolul al XIX-lea, va fi inclusă în dicționarul și gramatica lui Clemens (v. capitolul 1.2.), ca și cum ar fi fost ocurentă și în uzul lingvistic normal.

În ceea ce privește traducerile biblice din perioada 1640-1780, în NTB (1648), este atestată afirmația prin reluarea verbului (8), iar în BVBl (1760-61), se mai folosește forma adevărat, varianta lui adevăr (9). În același timp, se observă folosirea foarte frecventă a lui $a s ̧(e) a$ : atât ca element al construcției $a s ̧(e) a$ e, cât și ca o formă independentă. Perifraza este atestată, mai ales, tot în NTB (1648) și BVBl (1760-61), cf. (10 a, b). BBuc (1688) prezintă, pe de o parte, generalizarea lui $a s ̧(e) a$ și, pe de alta, folosirea lui fără suport verbal (11), lucru care demonstrează gramaticalizarea acestui adverb modal ca particulă afirmativă. De asemenea, folosirea lui aşa cu funcție afirmativă este atestată în primul dicționar al limbii române, Codex Caransebesiens, scris pe la mijlocul secolului al XVII-lea (DVL, 1650 , p. 74). În schimb, ei nu mai este atestat în niciunul dintre pasajele reperate din traducerile de mai sus.

(8) şi zise lor Iisus: Creadeți că poci face aceasta voao? Ziseră Lui: Creadem, Doamne (NTB, 1648) (Mt 9, 28).

(9) Iară ea au răspuns și au zis Lui: ,Adevărat, Doamne, că și cățăii mâncă supt masă din sfârmiturile pruncilor" (BVB1, 1760-61) (Mc 7, 28).

a. Ia zise: Aşia-i, Doamne, că şi cînii mănîncă den fărîmele cealea ce cad den masa domnilor săi (NTB, 1648) (Mt 15, 27).

b. Iară ea au zis: „Așa e, Doamne, că și cânii mâncă din sfârmiturile ce cad din masa domnilor săi”" (BVB1, 1760-61) (Mt 15, 27).

(11) Iară ea zise: „Așea, Doamne, că și cîinii mănîncă den fărîmele cealea ce cad den masa domnilor lor" (BBuc, 1688) (Mt 15, 27). 
1.2. Româna premodernă (1780-1830), modernă (1830-1880) și contemporană (de după 1880)

În perioada următoare ${ }^{4}$, mai este comună exprimarea afirmației prin reluarea obiectului întrebării, cf. Micu (1780) şi Șincai (1805) (12); se mai folosește, în continuare, afirmația cu $a s ̧ a$, acest lucru fiind atestat atât în lucrări teoretice, cât și în texte (13):

(12) Știi domnia-ta românește?

Știu, căci?

(Micu, 1780, p. 109; Şincai, 1805, p. 219)

(13) Marturii carii mărturisesc la așa (adică carii zic că au văzut și au auzit) sînt priimiți

(PC, 1780, p. 124)

Formele $e i$ și $i i$ sunt menționate numai la nivel teoretic, într-un dicționar și într-o gramatică, semnate, de altfel, de același autor transilvănean (Clemens, 1821a, pp. 48, 55, 302; Clemens, 1821b, p. 50).

În același timp, își fac apariția cuvinte afirmative noi. Primul dintre ele este înregistrat numai în surse transilvănene, sub formele: iea (Micu, 1780, p. 66; Şincai, 1805, p. 180), ie, | (LB, 1825, p. 271), ie, éa (Alexi, 1826, p. 166), aceste grafii însemnând că erau două particule diferite, ie și ia, sau, cel mai probabil, aceeași particulă cu o pronunție oscilantă sau intermediară între ie și $i a([j \mathrm{j}] \sim[j \mathrm{j}]$ sau $[\mathrm{j} \varepsilon])$. În orice caz, textele literare nu-l consemnează. În schimb, varianta ie cunoaște o răspândire destul de mare (cel mai probabil, tocmai de atunci) în graiurile populare din Banat sau, în general, din Transilvania, devenind o marcă caracteristică a acestei zone.

Cel de-al doilea cuvânt afirmativ nou a fost particula $d a$. Conform lui Frâncu (2009, p. 405), ea nu este consemnată în textele din epoca veche, începând să fie atestată și răspândindu-se abia în prima jumătate a secolului al XIX-lea şi, mai ales, în perioada Regulamentului Organic, deci între anii 1831-1832 (Țara Românească și, respectiv, Moldova) și 1858.

Afirmația lui Frâncu este confirmată de analiza unui corpus de texte literare din perioada respectivă. Țiganiada (Budai-Deleanu, 1800-1812), cel mai cuprinzător text original de la începutul secolului al XIX-lea, nu înregistrează nicio ocurență a lui $d a$ (tabelul 2) (de altfel, aşa, care este foarte frecvent acolo, nu apare decât cu sensul de 'astfel, asemenea, atât(a)'). Dintre atestările particulei $d a$ reperate de Niculescu (1961, p. 480), cele mai vechi se află la doi autori munteni: într-o poezie a lui Iancu Văcărescu (scrisă probabil între 1815-1817) (14a) și într-o scenetă de Heliade-Rădulescu (1837) (14b). Tot atunci, ea apare în gramatica lui HeliadeRădulescu (1828, p. 71) și în dicționarul lui Vaillant (1839, pp. 34, 131). Alte

\footnotetext{
${ }^{4}$ Periodizarea istoriei limbii române este preluată din Pană Dindelegan (2013, pp. 3-5).
} 
atestări au fost identificate în textele literare de la începutul anilor 1840, atât la autorii munteni (14c, d), cât și la cei moldoveni (15a, b):

(14)

a. Ce zic? Să mă urască? / Da! Invinovățire / De dragostea-mi prea multă / Ea poate să-mi găsească (Văcărescu, 1815-1817)

b. COMAN: Imi pare bine că şi-a cumpărat vitişoare; bun băiat mi-a trimis Dumnezeu.

VASILE: Da, flăcău ca dînsul puțini, moș Comane.

(Heliade-Rădulescu, 1837)

c. N-apucă să zică fatalul său da, / Şi-ncepu să sară sub iutea suflare (HeliadeRădulescu, 1840)

d. Să vă fac o întrebare: / Ceea ce naște au fată / Nu răposează vrodată? /

Da, da-i-au răspuns - să poate / cîte-n lume nasc, mor toate

(Pann, 1841)

(15)

a. nu-i vreo pagubă c-or muri cîteva sute de mojici, de vreme ce au pierit atîța boieri. Da, să-i omoare de istov (Negruzzi, 1840)

b. La vrâsta mea să cer eu un rendez-vous? Da, cerul trebuia să se acopere cu nouri, soarele trebuia să se întunece (Kogălniceanu, 1841)

Operele literare clasice din secolul al XIX-lea prezintă folosirea din ce în ce mai regulată a acestei particule. Bineînțeles, un număr mic de ocurențe din proza lui Eminescu $(1872,1876)$ și Creangă (1880-81) se explică prin caracterul ei narativ, destul de multe ocurențe fiind înregistrate, evident, în piesele lui Alecsandri (1850, 1855) şi ale lui Caragiale (1883) (tabelul 2). În același timp, se pot observa diferite particularități: la Alecsandri, în paralel cu $d a$, se mai folosește forma dar; iar la Caragiale, $d a$ este întărit deseori prin așa $(d a, a s ̧ a)$.

Tabelul 2. Afirmația prin $d a$ în textele literare din secolul al XIX-lea

\begin{tabular}{|l|c|c|c|}
\hline & Cuvinte în total & $\boldsymbol{d a}$ & \% \\
\hline Budai-Deleanu, 1800-12 & 69841 & 0 & 0,0000 \\
\hline Pann, 1847 & 51137 & 4 & 0,0078 \\
\hline Alecsandri, 1850 & 13554 & 7 & \\
\hline Alecsandri, 1855 & 13748 & 1 & \\
\hline & 27302 & 8 & 0,0293 \\
\hline Filimon, 1863 & 75789 & 32 & 0,0422 \\
\hline Eminescu, 1872 & 14682 & 5 & \\
\hline Eminescu, 1876 & 10322 & 6 & \\
\hline & 25004 & 11 & 0,0439 \\
\hline Slavici, 1880 & 38655 & 27 & 0,0698 \\
\hline Creangă, 1880-81 & 25065 & 1 & 0,0039 \\
\hline Caragiale, 1883 & 21047 & 73 & 0,3468 \\
\hline
\end{tabular}


Traducerile biblice din perioada premodernă, modernă și chiar cea contemporană (tabelul 3) folosesc, până la începutul secolului al XX-lea, afirmația așa, deseori sub forma construcției așa e(ste), care stă la baza folosirii afirmative a lui $a s ̧ a$, și adevărat, uneori în varianta $c u$ adevărat. Particula $d a$ o introduc în limbajul biblic abia traducătorii din secolul al XX-lea. Primul care o folosește în mai toate cazurile este protestantul Cornilescu (1924). Traducătorii ortodocși din această perioadă, Radu și Galaction (1939), care și ei optează pentru folosirea lui $d a$, revin, totuși, în unele cazuri, la formele mai vechi adevărat și aşa. Fără nicio îndoială, opțiunile traducătorilor sunt dictate și de apartenența lor confesională. Cornilescu, ca protestant, preferă un limbaj autentic, apropiat de limba română uzuală din vremea lui. Ceilalți, fiind ortodocși, continuă limbajul biblic „clasic”, ancorat în tradiție. Abia în traducerile ortodoxe ulterioare, B (1999) și BA (2012), folosirea lui $d a$ este generală.

În concluzie, în traducerile Bibliei, $d a$ apare destul de târziu, în prima jumătate a secolului al XX-lea, și se impune în mod definitiv numai în a doua jumătate a acelui secol. Bineînțeles, acest lucru poate fi pus pe seama caracterului arhaizant al limbajului biblic și a imitării de către traducătorii noi a traducerilor vechi sau cel puțin a stilului lor. Astfel, ar fi o altă dovadă a caracterului recent sau, eventual, neliterar al lui $d a$.

Tabelul 3. Exprimarea afirmației în traduceri biblice românești (după 1780)

\begin{tabular}{|c|c|c|c|c|c|c|c|}
\hline & Mt 9, 28 & Mt 11, 26 & Mt 13,51 & Mt 15,27 & Mc 7, 28 & In 11, 27 & In 21,15 \\
\hline BBI, 1795 & aşa & aşea & aşea & aşa e & adevărat & aşea e & aşea e \\
\hline NT, 1838 & așa & adevărat & așa & adevărat & adevărat & așa este & aşa \\
\hline B, 1914 & așa & adevărat & aşa & adevărat & adevărat & aşa este & aşa \\
\hline BN, 1921 & aşa & aşa & aşa & aşa este & aşa este & aşa este & așa este \\
\hline BC, 1924 & da & da & $\mathrm{da}$ & da & da & da & da \\
\hline B, 1939 & da & adevărat & da & adevărat & adevărat & $\mathrm{da}$ & da \\
\hline B, 1999 & $\mathrm{da}$ & da & $\mathrm{da}$ & $\mathrm{da}$ & $\mathrm{da}$ & $\mathrm{da}$ & $\mathrm{da}$ \\
\hline BA, 2012 & $\mathrm{da}$ & $\mathrm{da}$ & $\mathrm{da}$ & $\mathrm{da}$ & $\mathrm{da}$ & $\mathrm{da}$ & $\mathrm{da}$ \\
\hline
\end{tabular}

\begin{tabular}{|c|c|c|c|c|c|c|c|}
\hline & FA 5, 8 & FA 22, 27 & $\operatorname{Rm~3,~} 29$ & FIm 1, 20 & Ap 14, 13 & Ap 16, 7 & Ap 22, 20 \\
\hline BBI, 1795 & aşea & așea & adevărat & adevărat & așa & aşea & așea \\
\hline NT, 1838 & cu adevărat & aşa & adevărat & așa & așa & așa & aşa \\
\hline B, 1914 & cu adevărat & aşa & adevărat & așa & așa & aşa & aşa \\
\hline BN, 1921 & aşa este & așa este & (este) & așa & așa & așa & așa \\
\hline BC, 1924 & da & da & $\mathrm{da}$ & da & da & da & da \\
\hline B, 1939 & da & de bună seamă & de bună seamă & aşa & da & aşa & da \\
\hline B, 1999 & da & da & $\mathrm{da}$ & $\mathrm{da}$ & da & da & da \\
\hline BA, 2012 & $\mathrm{da}$ & $\mathrm{da}$ & $\mathrm{da}$ & $\mathrm{da}$ & $\mathrm{da}$ & $\mathrm{da}$ & $\mathrm{da}$ \\
\hline
\end{tabular}




\section{PERSPECTIVA AREALĂ}

\subsection{Particulele ei, ie și $d a$ în context areal}

În ceea ce privește formele folosite ca particule afirmative în limbile Europei de est (tabelul 4), se pot distinge mai multe arii lingvistice care se suprapun, în linii mari, cu frontierele vechilor state multietnice din zona respectivă. Particula afirmativă specifică fiecărei arii se datorează limbii predominante în aceste state din cauza statutului sale de limbă oficială sau vernaculară. Acestea au fost: polona în Republica Celor Două Naţiuni, suedeza în Suedia și Finlanda, germana în Prusia și Austro-Ungaria, rusa în Imperiul Rus și limbile slave meridionale (bulgara și sârba) în partea balcanică a Imperiului Otoman. Astfel, se pot distinge trei arii mari:

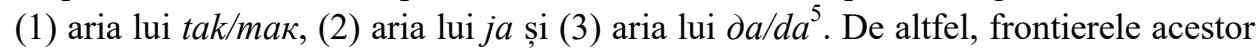
arii nu sunt fixe, schimbările politice ulterioare reflectându-se și în exprimarea afirmației, de exemplu, în variantele traseanka și surjik ale limbilor bielorusă și, respectiv, ucraineană, în locul formei standard $\operatorname{ma\kappa }$ (echivalentă cu tak din polonă), se folosește $\partial a$ (ca în rusă).

Tabelul 4. Particule afirmative în limbile Europei de est ${ }^{6}$

\begin{tabular}{|c|c|c|c|c|c|}
\hline \multirow{2}{*}{ Limbă } & \multicolumn{5}{|c|}{ Particulă afirmativă } \\
\hline & $=$ 'aşa, astfel' & EI & JA & $\mathrm{DA}$ & alte particule \\
\hline polonă & tak & & & & \\
\hline lituaniană & taip & & & & \\
\hline bielorusă & maк & & & & \\
\hline ucraineană & так & & & & \\
\hline suedeză & & & ja & & \\
\hline finlandeză & & & joo (fam.) & & kyllä \\
\hline germană & & & ja & & \\
\hline estonă & & & jaa & & \\
\hline
\end{tabular}

${ }^{5}$ Pornind tot de la forma particulei afirmative folosite, în lucrarea De vulgari eloquentia, Dante Alighieri (1304-1307) a identificat o limbă în care se răspunde afirmativ cu jo şi o altă limbă, compusă, de fapt, din trei limbi, dintre care în prima se afirmă cu oil, în cea de-a doua cu $o c$ şi în cea de-a treia cu sì. Spre deosebire de Dante, care a separat astfel limba germanică şi limbile romanice principale din vremea lui, ariile pe care le-am delimitat în articolul de față nu reprezintă, în niciun caz, o tentativă de clasificare a limbilor în cauză, ci trebuie tratate ca simple izoglose care marchează fenomene de geografie lingvistică, limbile acestea fiind, uneori, destul de îndepărtate unele de altele din punct de vedere genetic (unele dintre ele nici nu sunt limbi indo-europene). Bineînțeles, fără să se nege valoarea documentară a observațiilor lui Dante, clasificarea pe care a propus-o nu este decât o curiozitate din perioada unei lingvistici preștiințifice, criteriul ales (cu tot simbolicul lui) având un caracter cu totul arbitrar și întâmplător.

${ }^{6}$ În ceea ce privește limbile slave, tabelul este bazat pe datele furnizate de Dalewska-Greń (1997, p. 408). 


\begin{tabular}{|c|c|c|c|c|c|}
\hline \multirow{2}{*}{ Limbă } & \multicolumn{5}{|c|}{ Particulă afirmativă } \\
\hline & $=$ 'aşa, astfel' & EI & JA & DA & alte particule \\
\hline letonă & & & $j \bar{a}$ & & \\
\hline caşubă & & & jo & & \\
\hline sileziană & & & $j a$ & & \\
\hline soraba de jos & & & jo & & \\
\hline soraba de sus & & & & & haj \\
\hline cehă & & & jó (fam.) & & ano \\
\hline slovenă & & & $j a$ (fam.) & $d a$ & \\
\hline croată & & & ja (reg.) & $d a$ & \\
\hline slovacă & & & & & ano; hej (fam.) \\
\hline maghiară & & & $j a$ (fam.) & & igen \\
\hline română & așa (reg.) & $e i$ (înv.) & ie (reg.) & $d a$ & \\
\hline sârbă & & & & $\partial a$ & \\
\hline macedoneană & & & & $\partial a$ & \\
\hline bulgară & & & & $\partial a$ & \\
\hline rusă & & & & $\partial a$ & \\
\hline bielorusă (traseanka) & & & & $\partial a$ & \\
\hline ucraineană (surjik) & & & & $\partial a$ & \\
\hline albaneză & & & & & po \\
\hline greaca modernă & & & & & $v \alpha i$ \\
\hline greaca veche & & & & & $v \alpha i$ \\
\hline latină & & & & & ita \\
\hline slava veche & & EH & & & \\
\hline slavonă & & EЙ & & & \\
\hline
\end{tabular}

\subsection{Particulele afirmative ca împrumuturi}

După cum rezultă din tabelul 4, trei dintre cele patru particule afirmative propriu-zise identificate în evoluția istorică a limbii române, ei, ie și da, demonstrează legături evidente cu limbile din zonă: slava veche/slavonă, germană și, respectiv, limbile slave meridionale și rusă. Ținând cont de contextul istoric, politic și cultural, particulele din română par a fi împrumuturi din limbile menționate mai sus. În același timp, potrivit lui Swadesh $(1952,1971)$ și lingviștilor de la Max Planck Institute (Haspelmath \& Tadmor, 2009; Tadmor, Haspelmath \& Taylor, 2010), cuvintele de bază sunt mai rezistente la schimbare, adică la înlocuirea lor prin alte cuvinte și, deci, prin împrumuturi din alte limbi. Trebuie remarcat, totuși, că listele cuvintelor de bază propuse de cercetătorii menționaţi mai sus, adică atât lista Swadesh (varianta extinsă din 1952 și lista definitivă cu o sută de cuvinte din 1971), cât și lista Leipzig-Jakarta de o sută de cuvinte (2009), nu înregistrează afirmaţia 
$y e s^{7}$, deși conțin, în același timp, negația not. Acest lucru rezultă din faptul că o afirmație generală, exprimată printr-un singur cuvânt, poate să nu apară deloc într-o limbă, mai ales într-un stadiu mai vechi al acesteia, ceea ce poate fí legat de tendința de a multiplica noțiuni detaliate în lipsa unor noțiuni generale. În aceste condiții, afirmația trebuie exprimată prin reluarea întrebării. Cu toate acestea, limbile care nu aveau inițial o particulă afirmativă propriu-zisă tind s-o creeze în cursul evoluției lor, precum limbile romanice care au deja forme afirmative generalizate, spre deosebire de limba latină din care provin.

Tabelul 5. Frecvența particulelor afirmative în limbi europene alese

\begin{tabular}{|c|c|c|c|c|c|}
\hline Limbă & Particulă afirmativă & \multicolumn{2}{|c|}{ Număr de ocurențe } & \multicolumn{2}{|c|}{ Loc } \\
\hline turcă & evet & \multicolumn{2}{|c|}{1220531} & \multicolumn{2}{|c|}{12.} \\
\hline letonă & $j \bar{a}$ & \multicolumn{2}{|c|}{13423} & \multicolumn{2}{|c|}{18.} \\
\hline portugheza europeană & $\operatorname{sim}$ & \multicolumn{2}{|c|}{773323} & \multicolumn{2}{|c|}{25.} \\
\hline greaca modernă & $v \alpha i$ & \multicolumn{2}{|c|}{1076681} & \multicolumn{2}{|c|}{26.} \\
\hline franceză & $\begin{array}{l}\text { oui } \\
\text { ouais }\end{array}$ & $\begin{array}{l}851403 \\
213311\end{array}$ & 1064714 & $\begin{array}{r}45 . \\
137 .\end{array}$ & 38. \\
\hline engleză & $\begin{array}{c}\text { yes } \\
\text { yeah }\end{array}$ & $\begin{array}{l}1272870 \\
1499782\end{array}$ & 2772652 & $\begin{array}{l}71 . \\
60 .\end{array}$ & 33. \\
\hline
\end{tabular}

În plus, în limbile în care există particule specializate pentru exprimarea afirmației, acestea aparțin vocabularului lor de bază, lucru care este demonstrat de locurile superioare ocupate de particulele în cauză pe listele de frecvență a lexicului limbilor contemporane, realizate în baza corpusului lingvistic reprezentat de traducerile dialogurilor de filme, open subtitles $^{8}$ (tabelul 5). Astfel, chiar dacă limbile selectate ${ }^{9}$ diferă între ele în această privință, particulele afirmative din aceste limbi se află în prima sută de cuvinte, uneori chiar printre primele 20 , cf. evet din turcă - locul 12 ., $j \bar{a}$ din letonă -18 ., sim din portugheza europeană -25 ., vaí din greaca modernă -26 ., oui din franceză - 45., yes din engleză - 71.). Dacă se iau în considerare și cele mai

\footnotetext{
${ }^{7}$ Listele au fost întocmite în limba engleză, dar cuvintele respective reprezintă, de fapt, noțiuni de bază considerate universale și exprimate explicit în orice limbă.

${ }^{8} \mathrm{Cu}$ toate că open subtitles constituie, de fapt, traduceri din engleză în alte limbi, iar o parte dintre aceste traduceri s-au făcut, cel mai probabil, prin utilizarea unor instrumente de traducere automată, acesta este un corpus vast de texte paralele în mai multe limbi, care permite efectuarea unor cercetări lingvistice, inclusiv întocmirea unor liste de frecvență. Acestea pot fi consultate pe site-ul: https://github.com/hermi tdave/FrequencyWords/tree/master/content/2016.

${ }^{9} \mathrm{Au}$ fost selectate limbi europene în care particula afirmativă este monosemantică (adică nu exprimă și alte sensuri) şi nonomonimică (adică nu este identică din punct de vedere formal cu un alt cuvânt cu un alt sens sau alte sensuri), întrucât listele de frecvență folosite nu țin cont de sensul unităților lexicale și indică doar locul ocupat de formele ocurente în corpus.
} 
frecvente variante familiare ale particulelor afirmative din franceză și engleză, adică ouais și, respectiv, yeah, numărul de ocurențe ale acestora adăugându-se celui ale particulelor standard, frecvența afirmativelor din cele două limbi devine și mai mare (locul 38. în cazul francezei și chiar locul 33. în cazul englezei). Până la urmă, particulele afirmative din limbile de mai sus ajung să ocupe un loc printre primele 40 de cuvinte de bază ${ }^{10}$.

Astfel, atunci când într-o limbă nu există o particulă afirmativă, ea tinde să fie creată prin mijloace proprii sau împrumutată dintr-o altă limbă, iar în cazul în care ea există deja, rămâne destul de stabilă (ca element al vocabularului de bază) și se împrumută mai greu. În ambele cazuri, împrumutul se face, în special, din motive de prestigiu sau ca manifestare a modei, mai ales în condițiile în care limba respectivă este concurată de o altă limbă, cu statut cultural superior, din care pătrund în ea o serie de citate spontane și necontrolate.

\subsection{Contextul intern vs. cel extern. Teoria punctelor de sprijin}

În același timp, împrumutul poate fi condiționat de factori interni. Introducerea în limba 1 a unui element din limba 2 poate fi facilitată de existența anterioară în limba 1 a unui element care ,atrage” elementul din limba 2, deci, cu alte cuvinte, de existența unui cadru favorabil împrumutului lingvistic respectiv. Acest element existent deja în limba 1 reprezintă ,un punct de sprijin” pentru elementul împrumutat din limba 2. Teoria ,punctelor de sprijin”, pe care am formulat-o mai sus, coincide cu cea a „ușilor întredeschise” (Abraham, 2011, pp. 234, 270), cele două teorii diferind, de fapt, doar prin metafora folosită. Poate fi aplicată, în special, acelor împrumuturi lingvistice care, în general, sunt mai rare, precum cele lexicale din categoria cuvintelor care denumesc noțiuni de bază (acestea fiind foarte rezistente la influența străină, cf. teoria lui Swadesh) sau cele extralexicale: morfosintactice și derivative. Prin urmare, ea s-ar putea aplica și în cazul particulelor afirmative care fac obiectul acestui studiu.

\section{ORIGINEA PARTICULELOR AFIRMATIVE DIN ROMÂNĂ}

\subsection{Originea lui așa}

Etimonul lui aşa este același adverb latin $s \bar{c} c$ care stă la baza formelor afirmative din limbile romanice occidentale: sì din italiană, sí din spaniolă și catalană, sim din portugheză, schi din engadineză. Cu privire la originea elementului de întărire

\footnotetext{
${ }^{10}$ Din păcate, cazul românei nu este relevant, clasamentul neținând cont de sensul cuvintelor și incluzând sub cuvântul $d a$ atât afirmația 'da', cât și infinitivul '(a) da' (în lipsa diacriticelor, și forma 'dă').
} 
antepus lui sic și continuat sub forma vocalei $a$-, părerile sunt împărțite, fiind menționate următoarele forme din latină: $a c$ (DER, 2002, p. 54; Frâncu, 2009, p. 405-406), ad (Frâncu, 2009, p. 405), eccum (MDA, 2010, I, p. 118). În schimb, elementul de la finala cuvântului este propriu formanților adverbiale din română (DER, 2002, p. 54). Diversele variante diacronice și diatopice înregistrate de MDA (2010, I, p. 118) consemnează, cel puțin parțial, etapele succesive ale evoluției formei în cauză: aşi (învechit); așă, așe, așea, aşia (învechit și regional); şa (Transilvania). De altfel, pentru a exprima sensul propriu-zis al lui așa, cel de adverb modal, alte limbi romanice recurg și ele la variantele extinse ale lui $s \bar{c} c$, cu un element de întărire antepus, de cele mai multe ori identic cu cel din română, cf. it. così vs. fr. ainsi, sp. así, port. assim.

Având în vedere faptul că forma $a s ̧ a$ provine, până la urmă, din lat. sīc, româna se sincronizează, prin folosirea ei cu sens afirmativ, cu mai multe limbi romanice occidentale, care, totuși, mai păstrează diferența formală dintre adverbul de mod și particula afirmativă.

\subsection{Originea lui ei și ie}

Referitor la originea lui ei afirmativ, MDA (2010, I, p. 793) indică etimologia slavă veche; în schimb, varianta ee ar fi provenit, potrivit lui Frâncu (2009, p. 405), din conjuncția copulativă latină et. Pe de o parte, legătura evidentă dintre rom. ei din română şi corespondentul său exact din slava veche (sau, mai degrabă, din slavonă) este confirmată și prin faptul că formei românești ei din textele traduse îi corespunde, în mai toate cazurile, un $e i$ din textul slavon, un transfer lingvistic direct fiind cea mai simplă opțiune de traducere a unui cuvânt problematic. Cu toate acestea, nu e exclus ca slavonismul ei să fi intrat în româna veche, fiind asociat cu ee (care a acționat ca un punct de sprijin), o variantă a formei $e$, folosită de cele mai multe ori drept conjuncție adversativă, ambele continuând lat. et. Astfel, explicațiile cu privire la originea ei oferite de Frâncu și MDA se completează reciproc.

În ceea ce privește particula afirmativă ie (sau chiar ię, adică $[j \varepsilon]$ ), Pușcariu (1940, p. 280) o consideră o prescurtare din este, pe când în DER (2002, p. 409), se dă, ca etimonul ei, germ. $j a$. Îmbinând cele două puncte de vedere, considerăm că la baza rom. ie se află germanismul ja, suprapus formei românești $e$ (adică este), folosită cu sensul de 'da', ca prescurtare de la așa e. Trebuie remarcat, în acest sens, că în graiurile din Transilvania, secvența [ja] evoluează spre [je]; prin urmare, germanismul $j a$ ar fi devenit, oricum, ię, lucru consemnat prin oscilațiile grafice din lucrările menționate mai sus (v. capitolul 1.2.), de exemplu, scrierea cu litere latine ie vs. cea cu litere chirilice я $(=i a)(\mathrm{LB}, 1825$, p. 271). Pe de altă parte, în graiurile transilvănene, este poate avea pronunția [jeste] (provenind din mai vechiul iaste). Prin urmare, și prescurtarea lui, $e$, poate fi realizată din punct de vedere fonetic ca [jz]. Pe 
de altă parte, Mihăilă (1960, p. 215) diferențiază formele ie și ia, susținând că prima se folosește în varietățile dialectale din Banat și Transilvania, iar cea de-a doua - în cele din Transilvania. Astfel, ie ar fi provenit din ieste, iar ia - din forma germană ja.

\subsection{Originea lui $d a$}

Explicația lui da prin lat. ita, propusă de Massey (2008), nu este plauzibilă din motive formale (fonetice) și cronologice. În primul rând, sonorizarea oclusivei intervocalice, mutarea accentului și afereza primei silabe sunt fenomene atât de rare în evoluția istorică a limbii române, încât acumularea lor într-un singur caz devine, de-a dreptul, neverosimilă. În al doilea rând, e imposibil ca forma $d a$ moștenită din latină să fi rămas latentă până în secolul al XIX-lea, fără să fie consemnată în scris.

În schimb, este posibilă o explicație internă bazată pe faptul că, înainte de generalizarea lui $d a$, în sursele din secolul al XIX-lea, se folosesc, pe lângă $d a$, și formele dară sau dar. Din punct de vedere diacronic, cea mai veche formă este dară, cu varianta deară, notată de MDA (2010, I, p. 599). Forma dar, la rândul ei, derivă din dară, iar $d a$ - din dar (ca o conjuncție adversativă și concluzivă, fiind notată, în româna actuală, chiar ca $d a^{\prime}$ ). Această succesiune a formelor este confirmată de atestările lor în texte vechi (v. CETRV, ROMTEXT). Forma $\operatorname{dar}(\breve{a})$ provine, probabil, din lat. *de + vero sau reprezintă un compus: de + iară , v. DER (2002, p. 278-279).

Funcția inițială a acestor forme este cea de conjuncție adversativă, concluzivă și interogativă, sensul de particulă afirmativă fiind ulterior. Formarea unei particule afirmative de la niște conjuncții este atestată în mai multe limbi; de exemplu, afirmația $\partial a / d a$ din limbile slave provine dintr-o conjuncție. Astfel, dară, dar și da pot fi considerate mai multe variante ale unui singur cuvânt, având, în principiu, aceleași sensuri (adversativ, concluziv, interogativ, afirmativ).

De exemplu, în textele literare de după 1830, afirmația este exprimată atât prin $d a r$, cât și prin $d a$, cf. două pasaje din poezia lui Heliade-Rădulescu sau două fraze succesive dintr-un text semnat de Kogălniceanu, cu dar (16a, b) și da (17a, b), ambele forme având un sens afirmativ.

a. Când la judecată mă voi arăta [...] / Tu și-atunci, o, înger, dar! mă vei urma! (Heliade-Rădulescu, 1833)

b. Dar, dar, răspunse N. Măcărescu, asta a fi până când te-i amoreza de vro domnişoară de a noastră.

(Kogălniceanu, 1850)

(17)

a. N-apucă să zică fatalul său da, / Și-ncepu să sară sub iutea suflare.

(Heliade-Rădulescu, 1840)

b. Da, da, frățică, urmă a vorbi dl Stihescu, român sunt și român vreau să mor.

(Kogălniceanu, 1850) 
Într-un mod şi mai evident, acest lucru se poate observa în teatrul lui Alecsandri, cf. o serie de replici, în care dar are sensul de 'dar' (18) și 'da' (19); de asemenea, da poate însemna acolo atât 'dar' (20), cât și 'da' (21):

(18) LEONAȘ: D-apoi eu!... Ce n-am cercat să te pot întâlni!... dar în zadar!

(Alecsandri, 1855)

(19) CHIRIȚA: D-lui ține poștile?

BONDICI: Dar.

(Alecsandri, 1850)

(20) CHIRIȚA: [...] Hai, du-te cu domnu profesor de învață frumuşel, că ți-oi face straie de moda nouă.

GULIȚĂ: Da... cal mi-i cumpăra?

(Alecsandri, 1855)

(21) CHIRIȚA: [...] Am să ți-l cânt: / Of, of, of, ce supărare, / De-a avea o fată mare!

AFIN: Da, il știu, soro... l-am auzit...

(Alecsandri, 1850)

Ulterior, în româna standard, sensurile respective au fost delimitate și la nivel formal: dar - conjuncție adversativă, concluzivă și interogativă, da - adverb afirmativ. Forma dară devine varianta nonstandard a lui dar, care, de altfel, în limba familiară, se folosește sub forma $d a$, devenind, deci, identic din punct de vedere formal cu afirmativul $d a$.

Specializarea formală și semantică a celor două variante ale cuvântului dar (dar $-d a)^{11}$ în limba standard (literară) s-ar fi produs în mod similar cu scindarea în două forme, diferențiate ulterior și din punct de vedere semantic, a unor cuvinte precum: apoi, zeu, urcior (apoi - apăi > păi, zeu - zău, urcior - ulcior); nota bene, expresia (a)păi da este atestată, în același timp, și în varianta inițială, apoi dar. De asemenea, cu toate că diferențierea formală nu se face decât la nivel grafic, se produce o scindare semantică a lui ele (ele - iele) și, în paralel, a lui $e(e-i e)$.

Acceptarea formei prescurtate ca adverb afirmativ pare să confirme, în același timp, teoria formulată de Mańczak (1971) privind evoluția fonetică neregulată datorată frecvenței, conform căreia cuvintele folosite cel mai des, deci cele de bază, tind să evolueze fonetic în mod neregulat, cf. formele verbului 'a fi' în mai multe limbi și, în cazul de față, afirmația 'da', care prezintă o evoluție neregulată nu numai în română (22a), ci și în polonă (22b), franceză (22c) sau engleză (22d):

rom. $d a r>d a$

pol. $t a k \boldsymbol{o}>$ tak

fr. oill $>$ oui

engl. yes $>$ yeah, yeh

\footnotetext{
${ }^{11}$ Astfel de diferențieri formale și semantice există, bineînțeles, și în alte limbi, cf. pol. jako 'ca' jak 'cum', żłóbek 'iesle' - żłobek 'creșă'.
} 
La Şăineanu (1929, p. 191), afirmativul dar este considerat deja regional, fiind asociat cu Moldova. În DEX (2009, p. 260) se dă ca regional și învechit, iar în MDA (2010, I, p. 600) - doar ca învechit (cu toate că $\operatorname{dar}(\breve{a})$ circulă și astăzi în unele regiuni din Moldova cu sensul de afirmație).

Conform altor interpretări, sensul dublu (conjuncție și particulă) al formelor dar și $d a$ reprezintă o contaminare între ele: „Este evidentă confuzia cu $d a$ afirmativ, atît în var. vulg. da „dar” cît și în var. vulg. dar „da”, folosită uneori de scriitori moldoveni" (DER, 2002, p. 279). Folosirea lui dar cu sensul de 'da' ar fi, deci, un fenomen ulterior, o manifestare a hipercorectitudinii.

În orice caz, în ceea ce privește sensurile afirmative, din dicționare și gramatici rezultă că dară și dar sunt anterioare lui da: Clemens (1821a, p. 243) nu înregistrează decât dară și dar (cu valoare emfatică, fiind traduceri ale lui doch din germană), Heliade-Rădulescu (1828, p. 71) - dar și da , Pleșoianu (1829, pp. 36-38) - dară, Vaillant (1839, pp. 34, 35, 131) - dară, dar și da , Aristia (1848, pp. 36, 100, 103, 109) - da, Peltechi Caminar (1854, p. 81) - dară, Pisone (1865, p. 96) și Costinescu (1870, p. 288) - da, iar Laurian și Massim (1871, pp. 1009, 1055) - dară și $d a$, constatând explicit că cel de-al doilea este o prescurtare de la primul. În ceea ce priveşte circulația mai mult moldovenească a afirmativului dar, este adevărat că folosirea paralelă cu sensul de 'da' a formelor dar și da apare, cel mai des, la autorii din Moldova, cf. citatele din Kogălniceanu, (16b) și (17b), și Alecsandri, (19) și (21). Totuşi, acest fenomen este atestat și la scriitorii din alte regiuni, ca, de exemplu, la munteanul Heliade-Rădulescu, (16a) și (17a). În plus, afirmativele dară și dar sunt înregistrate, pe lângă $d a$, în dicționarele și gramaticile din toate regiunile, și mai ales în cele din Țara Românească, precum Heliade-Rădulescu (1828), Pleșoianu (1829), Vaillant (1839). Astfel, folosirea afirmativă a lui dar mai ales în Moldova nu înseamnă decât că acolo acest uz se păstrează cel mai bine, dar înainte, era ocurent și în alte regiuni. Prin urmare, trebuie constatat că da provine din dar și, în ultimă instanță, din dară (și nu invers), părerea lui Laurian și Massim (1871), conform căreia $d a$ este o prescurtare a lui dară (ambele cu sens afirmativ), fiind justă, mai ales în condițiile în care aceștia chiar scriu din poziția martorilor evoluțiilor lingvistice în cauză. $\mathrm{Cu}$ toate acestea, convingerea că dar reprezintă o reacție hipercorectă față de $d a$ (și că, prin urmare, dar provine din $d a$ ) nu este cu totul eronată, în sensul că în perioada în care afirmativul a căpătat, în cele din urmă, o formă fonetică redusă, adică $d a$, a putut reapărea forma dar, prin analogie cu dar, formă pe care a păstrat-o adversativul, deci printr-o falsă convingere că, indiferent de sens, dar este forma corectă, iar $d a$ - cea incorectă.

Ținând cont de contextul areal, mai toate sursele se pronunță în favoarea etimologiei slave a lui $d a$, deși nu toate indică în mod specific care dintre limbile slave este sursa împrumutului. De exemplu, Puşcariu (1940, p. 280) se limitează la constatarea că afirmaţia $d a$ este împrumutată de la slavi. O etimologie slavă nedeterminată sau multiplă (bulgară, sârbă sau rusă) figurează la Mihăilă (1960, 
p. 216) și în dicționarele DEDR (1879, p. 89), DER (2002, p. 276), MDA (2010, I, p. 591).

În schimb, Rosetti (1986, p. 324) și DEM $(1978$, p. 97) reduc aria slavă din care ar fi provenit particula $d a$ la limbile slave meridionale. Niculescu (1961, p. 485), deși admite o sursă sârbo-croată și rusească a împrumutului (în cazul zonelor limitrofe limbilor în cauză), optează, totuși, pentru etimologia bulgară. Menționând, în general, „sursele slave”, Frâncu (2009, p. 405) insistă asupra originii rusești a lui $d a$, teorie susținută de răspândirea lui târzie, suprapusă cu perioada influenței rusești din timpul Regulamentului Organic. Dar, cu toate că influența rusească cuprinde nu numai perioada regulamentară, ci și ultimul sfert din secolul al XVIII-lea și primele decenii ale secolului al XIX-lea, nu i se poate atribui nici durata, nici intensitatea pe care le-a avut influența slavă meridională asupra limbii române vechi. Vorbitorii de română se aflau într-un contact direct cu slavii de sud chiar din perioada medievală, dovadă stând caracterul masiv al împrumuturilor slave, dintre care majoritatea sunt de factură slavă veche, bulgară, sârbă sau slavonă. Prin urmare, s-ar putea să fie o trăsătură a limbii vorbite care a început să fie reflectată în limba scrisă abia în secolul al XIX-lea. În acest sens, reținem din argumentația lui Massey (2008) (referitoare la originea latină a afirmativului $d a$ ) următoarea observație, considerândo valabilă pentru originea lui sud-slavă:

The earliest records for the Romanian language were, by definition, from the more educated registers. If $d a$, even as a borrowing, were a more colloquial term, it could have been a part of the language long before it first appears in writing (pp. 97-98).

Cele afirmate mai sus se potrivesc foarte bine cu presupusa evoluție a statutului afirmativului $d a$ din română. S-ar putea să fi fost un împrumut care a funcționat mai întâi în limbajul familiar-popular și nu a fost introdus decât ulterior în limba standard. Conform ELR (2001, p. 32), ,adverbul $d a$ a pătruns în română din slavă, la început în limba vorbită, apoi impus și în scris, fiind atestat în sec. 19, când se folosea în paralel particula adverbială dară, probabil intrat în limbă în a doua jumătate a sec. 18”. Un statut similar, familiar-popular, îl au în continuare jó din cehă, $j a$ din slovenă și ja din maghiară, împrumuturi din germană. Apariția târzie a lui $d a$ în texte (abia în secolul al XIX-lea) s-ar explica tocmai prin faptul că textele din secolele precedente de care dispunem au un preponderent caracter literar-formal. Așa-numitele „cărți populare” reprezintă, de fapt, o literatură cultă, de cele mai multe ori tradusă, caracterul ei popular rezultând din circulația lor destul de largă, chiar în popor. Abia literatura din secolul al XIX-lea, atât cea romantică, cât și cea realistă, inclusiv textele populare autentice (basme, povești etc.) culese de folcloriști, consemnează limba populară reală în toată bogăția ei, necenzurată de autorii culți.

Așadar, răspândirea și consemnarea în scris a lui $d a$ nu trebuie pusă în legătură cu influența rusească, ci cu ultimul val de balcanizare lingvistică și culturală, mai 
ales a Țării Românești și a Bucureștiului, din secolul al XIX-lea (în ciuda sfârșitului epocii fanariote și a începutului occidentalizării). Intrarea lui $d a$ în limba standard presupune circulația lui anterioară în Muntenia; într-adevăr, în ceea ce privește dicționarele și gramaticile din acest secol, $d a$ apare mai întâi în sursele sudice, cf. Heliade-Rădulescu (1828, p. 71), Vaillant (1839, pp. 34, 131) și Aristia (1848, pp. 36, 100, 103, 109), pe când în cele nordice din aceeași perioadă, se dau formele: ie/ia, cf. Alexi (1826, p. 166) și aşa, cf. Alexi (1826, p. 165), Vida (1833, p. 422, 507, 508), Peltechi Caminar (1854, pp. 60, 79). În aceste condiții, cea mai probabilă este sursa bulgărească a lui $d a$, în favoarea căreia pledează și Niculescu (1961, p. 482-485).

În concluzie, deși etimologia slavă a particulei afirmative $d a$ din română este acceptată practic în unanimitate, ea poate fi explicată prin aplicarea ,teoriei punctelor de sprijin", printr-o evoluție semantică internă a rom. $\operatorname{dar}(\breve{a}) \sim d a$, întărită de o influență externă, slavă. $\mathrm{Cu}$ alte cuvinte, slavul $d a$ a găsit în limba română un punct de sprijin favorabil pentru a putea fi adoptat în lexicul acesteia. În mod similar, potrivit lui Niculescu (1961, p. 481), Alexandru Rosetti presupunea (într-o comunicare orală) că întrebuințarea afirmativă a lui $\operatorname{dar}(\breve{a})$ ar fi putut genera afirmarea prin $d a$. De asemenea, un paralelism între cele două fenomene, adică afirmația prin dară și împrumutarea lui $d a$ din slavă, este remarcat în ELR (2001, p. 32). Cu toate acestea, nicio sursă dintre cele pe care le-am consultat nu dezvoltă această idee; Niculescu (1961, p. 481) constată doar că precedența istorică a lui $\operatorname{dar}(\breve{a})$ față de $d a$ nu poate fi stabilită, ambele procedee de afirmație fiind atestate în același timp, adică în secolul al XIX-lea.

\section{CONCLUZII}

Plasate în context areal, particulele afirmative românești ei, ie și $d a$ se impun a fi interpretate ca împrumuturi din: slavonă, germană și, respectiv, dintr-o limbă slavă. $\mathrm{Cu}$ toate acestea, având în vedere evoluția istorică și statutul lor special ca parte a vocabularului de bază, recurgem în cazul lor la teoria ,punctelor de sprijin”, care se inspiră din teoria „ușilor întredeschise” a lui Abraham (2011). În conformitate cu această teorie, considerăm că particula ei, împrumutată din slavonă, a putut folosi ca punct de sprijin conjuncția românească veche $e$, provenită din lat. et. În mod similar, particula $i e$, de origine germană, s-ar fi suprapus formei verbale din română $e$ ('este'). Introducerea în română a împrumutului slav $d a$, la rândul lui, a coincis cu evoluția semantică internă a formelor dară $\sim d a r \sim d a$ de la conjuncția adversativă la particula afirmativă.

În ceea ce privește originea precisă a lui $d a$, aceasta rămâne o problemă care necesită o analiză mai amplă, care să pornească de la aspectul diacronic raportat la 
cel diatopic. Totuși, luând în considerare rezultate analizei de mai sus, înclinăm mai degrabă spre explicația lui prin limbile slave meridionale (și, mai ales, prin bulgară) decât prin rusă.

\section{Anexa: Citate biblice reperate (după B, 1999)}

(Mt 9, 28) Credeți că pot să fac Eu aceasta? Zis-au Lui: Da, Doamne!

(Mt 11,26) Da, Părinte, căci aşa a fost bunăvoirea înaintea Ta.

(Mt 13, 51) Înțeles-ați toate acestea? Zis-au Lui: Da, Doamne.

(Mt 15, 27) Dar ea a zis: Da, Doamne, dar și câinii mănâncă din fărâmiturile care cad de la masa stăpânilor lor.

(Mc 7,28) Ea însă a răspuns şi I-a zis: Da, Doamne, dar şi câinii, sub masă, mănâncă din fărâmiturile copiilor.

(In 11, 27) [Crezi tu aceasta?] Zis-a Lui: Da, Doamne.

(In 21, 15) El I-a răspuns: Da, Doamne, Tu știi că te iubesc.

(FA 5, 8) Spune-mi dacă ați vândut țarina cu atât? Iar ea a zis: Da, cu atât.

(FA 22, 27) Și venind la el, comandantul i-a zis: Spune-mi, ești tu (cetățean) roman? Iar el a zis: Da!

$(\mathrm{Rm} 3,29)$ Nu este El și Dumnezeul păgânilor? Da, şi al păgânilor.

(Flm 1,20) Da, frate, eu te rog, fă-mi binele acesta in Domnul;

(Ap 14, 13) Da, grăiește Duhul, odihnească-se de ostenelile lor, căci faptele lor vin cu ei.

(Ap 16,7) Și am auzit din altar, grăind: Da, Doamne Dumnezeule, Atoțtiitorule, adevărate și drepte sunt judecățile Tale!

(Ap 22, 20) Cel ce mărturisește acestea zice: Da, vin curând. 


\section{BIBLIOGRAFIE}

\section{LUCRĂRI DE REFERINȚĂ}

Abraham, W. (2011). Spoken syntax in Cimbrian of the linguistic islands in Northern-Italy and what they (do not) betray about language universals and change under areal contact with Italo-Romance. In M.T. Putnam (ed.). Studies on German-Language Islands. Amsterdam / Philadelphia: John Benjamins Publishing Company, pp. 233-278.

Alighieri, D. (1304-1307). De vulgari eloquentia, http://www.thelatinlibrary.com/dante/vulgar.shtml.

Dalewska-Greń, H. (1997). Języki stowiańskie. Warszawa: Wydawnictwo Naukowe PWN.

ELR, 2001 = Sala, M. (coord.) (2001). Enciclopedia limbii române. București: Univers Enciclopedic.

Frâncu, C. (2009). Gramatica limbii române vechi (1521-1780). Iaşi: Casa Editorială Demiurg.

GALR, 2008 = Guțu Romalo, V. (coord.) (2008). Gramatica limbii române (ed. a 2-a) (vol. I-II). București: Editura Academiei Române.

GBLR, 2010 = Pană Dindelegan, G. (coord.) (2010). Gramatica de bază a limbii române. București: Univers Enciclopedic Gold.

Haspelmath, M. \& Tadmor, U. (eds.) (2009). Loanwords in the World's Languages: A Comparative Handbook. Berlin / New York: Mouton de Gruyter.

Holmberg, A. (2015). The Syntax of Yes and No. Oxford: Oxford University Press.

Mańczak, W. (1971). Evoluția fonetică neregulată datorată frecvenței. In Studii și Cercetări Lingvistice. 22 (6), pp. 479-586.

Massey, K.A. (2008). A Latin etymology for Romanian da = yes. In Ianua. Revista Philologica Romanica. 8, pp. 93-100.

Mihăilă, G. (1960). Imprumuturi vechi sud-slave în limba romînă: studiu lexico-semantic. București: Editura Academiei RPR.

Niculescu, A. (1961). Afirmarea prin da în limba romînă. In Studii și Cercetări Lingvistice. 12 (4), pp. 479-486.

Pană Dindelegan, G. (ed.) (2013). The Grammar of Romanian. Oxford: Oxford University Press.

Pană Dindelegan, G. (ed.) (2016). The Syntax of Old Romanian. Oxford: Oxford University Press.

Pușcariu, S. (1940). Limba română (vol. 1: Privire generală). București: Fundația pentru Literatură și Artă „Regele Carol II”.

Rosetti, A. (1986). Istoria limbii române. București: Editura Științifică și Enciclopedică.

Swadesh, M. (1952). Lexicostatistic Dating of Prehistoric Ethnic Contacts. In Proceedings of the American Philosophical Society. 96, pp. 452-463.

Swadesh, M. (1971). The origin and diversification of language (J. Sherzer, ed.). Chicago / New York: Aldine Atherton.

Tadmor, U., Haspelmath, M. \& Taylor, B. (2010). Borrowability and the notion of basic vocabulary. In Diachronica. 27 (2), pp. 226-246. DOI: 10.1075/dia.27.2.04tad.

\section{CORPUSURI}

CETRV = Corpus electronic al textelor românești vechi (1521-1640), http://textvechi.ro/web/guest. ROMTEXT = Corpus electronic de texte, adnotat și datat, al limbii române, https://romtext.ro/.

\section{TEXTE LITERARE ORIGINALE}

Alecsandri, V. (1850). Chirița în Iași, https://ro.wikisource.org/wiki/Chiri\%C8\%9Ba_\%C3\%AEn_Ia\% C8\%99i.

Alecsandri, V. (1855). Chirița în provincie, https://ro.wikisource.org/wiki/Chiri\%C8\%9Ba_\%C3\%AEn_ provincie. 
Budai-Deleanu, I. (1800-1812). Țiganiada, https://ro.wikisource.org/wiki/\%C8\%9Aiganiada.

Cantemir, D. (1705). Istoria ieroglifică, https://ro.wikisource.org/wiki/Istoria_ieroglific\% $\%$ C4\%83.

Caragiale, I.-L. (1883). O scrisoare pierdută, https://ro.wikisource.org/wiki/O_scrisoare_pierdut\% $\mathrm{C} 4 \% 83$.

Creangă, I. (1880-1881). Amintiri din copilărie, https://ro.wikisource.org/wiki/Amintiri_din_copil\% C4\%83rie.

Eminescu, M. (1872). Sărmanul Dionis, https://ro.wikisource.org/wiki/S\%C4\%83rmanul_Dionis.

Eminescu, M. (1876). Cezara, https://ro.wikisource.org/wiki/Cezara.

Filimon, N. (1863). Ciocoii vechi şi noi, https://ro.wikisource.org/wiki/Ciocoii_vechi_\%C8\%99i_noi.

Heliade-Rădulescu, I. (1833). Serafimul şi heruvimul, https://ro.wikisource.org/wiki/Serafimul_\%C8\% 99i_heruvimul.

Heliade-Rădulescu, I. (1837). Sărbătoare câmpenească pentru 30 august 1837. In A. Niculescu (1961). Afirmarea prin da în limba romînă. Studii și Cercetări Lingvistice. 12 (4), p. 480.

Heliade-Rădulescu, I. (1840). Foile și cărbunele (trad. după P. Viennet), https://ro.wikisource.org/wiki/ Foile_\%C8\%99i_c\%C4\%83rbunele.

Kogălniceanu, M. (1841). Iluzii pierdute. Un întâi amor, https://ro.wikisource.org/wiki/lluzii_pierdute. Un_\%C3\%AEnt\%C3\%A2i_amor.

Kogălniceanu, M. (1850). Tainele inimii, https://ro.wikisource.org/wiki/Tainele_inimii.

Negruzzi, C. (1840). Alexandru Lăpușneanul, https://ro.wikisource.org/wiki/Alexandru_L\%C4\%83pu\% C8\%99neanul.

Pann, A. (1841). Fabule și istorioare. In A. Niculescu (1961). Afirmarea prin da în limba romînă. Studii și Cercetări Lingvistice. 12 (4), p. 480.

Pann, A. (1847). Povestea vorbei, https://ro.wikisource.org/wiki/Povestea_vorbei.

Slavici, I. (1880). Moara cu noroc, https://ro.wikisource.org/wiki/Moara_cu_noroc.

Văcărescu, I. (1815-1817). La ochi. In A. Niculescu (1961). Afirmarea prin da în limba romînă. Studii și Cercetări Lingvistice. 12 (4), p. 480.

\section{TRADUCERILE TEXTELOR RELIGIOASE}

AC, 1563-66 = Coresi (ed.) (1563-1566). Lucrul Apostolesc. I. Bianu (ed.) (1930). Lucrul Apostolesc tipărit de diaconul Coresi la 1563. București: Cultura Națională.

B, 1914 = Biblia adică Dumnezeiasca Scriptură a Legii Vechi și a Celei Nouă. (1914). București: Tipografia Cărților Bisericești.

B, 1921 = Sfânta Scriptură a Vechiului și Noului Testament. (1921). București: Societatea Biblică pentru Britania și Străinătate.

B, 1939 = Biblia adică Dumnezeiasca Scriptură a Vechiului și a Noului Testament (V. Radu \& G. Galaction, trad.) (1939). București: Fundația pentru Literatură și Artă „Regele Carol II”.

B, 1999 = Biblia sau Sfânta Scriptură. (1999). Bucureşti: Editura Institutului Biblic şi de Misiune al Bisericii Ortodoxe Române.

BA, 2012 = B.V. Anania (ed.) (2012). Biblia sau Sfânta Scriptură, http://biblia.pentruviata.ro/.

BB1, 1795 = Biblia de la Blaj (S. Micu, trad.) (1795). Biblia de la Blaj 1795. (2000). Roma.

BBuc, 1688 = Biblia de la București (R. \& Ș. Greceanu, trad.). (1688). E. Munteanu (ed.) (2015). Biblia 1688 (Biblia de la București) (vol. 23-24). Iași: Editura Universității „Alexandru Ioan Cuza”.

BC, 1924 = Biblia sau Sfinta Scriptură a Vechiului şi Noului Testament (D. Cornilescu, trad.) (1924). Societatea Evanghelică Română, http://biblia.pentruviata.ro/.

BVBl, 1760-61 = Biblia Vulgata (P.P. Aron, trad.) (1760-1761). C. Mureşanu \& I. Chindriş (ed.) (2005). Biblia Vulgata, Blaj 1760-1761 (vol. 5). București: Editura Academiei.

CB, 1559-60 = Codicele Bratul. (1559-1560). A. Gafton (2001-2005). Codicele Bratul, http://media.lit. uaic.ro/gafton/index.html. 
CC, 1559-64 = Coresi (ed.) (1559-1564). Intrebare creștinească. I. Bianu (ed.) (1925). Întrebare creștinească tipărită de diaconul Coresi in Brașov la 1560. București: Cultura Națională.

CV, 1563-83 = Codicele Voronețean. (1563-1583). M. Costinescu (ed.) (1981). Codicele Voronețean. București: Editura Minerva.

ES, 1551-53 = Evangheliarul de la Sibiu. E. Petrovici \& L. Demény (ed.) (1971). Evangheliarul slavoromân de la Sibiu (1551-1553). Bucureşti: Editura Academiei RSR.

gr. $=$ R. Popowski \& M. Wojciechowski (ed.) (1994). Grecko-polski Nowy Testament. Warszawa: Oficyna Wydawnicza „Vocatio”.

lat. $=$ S. Kozłowski (ed.) (1864). Biblia tacińsko-polska (J. Wujek, trad.) (vol. 4). Wilno: Nakładem i Drukiem Józefa Zawadzkiego.

NT, 1838 = Noul Testament al Domnului și Mântuitorului nostru Iisus Hristos. (1838). Smirna: Tipografia lui Ant. Damian.

NTB, 1648 = Noul Testament de la Bălgrad. (1648), http://scriptura.pentruviata.ro/.

slav. = Библіа сиргчь Книги Священнаго Писанїя Ветхаго и Новаго Завъта. (1900). Санктпетербургъ: С ннодальная Тvпографїя.

TC, 1560-61 = Coresi (ed.) (1560-1561). Tetraevanghelul. F. Dimitrescu (ed.) (1963). Tetraevanghelul tipărit de Coresi (Brașov, 1560-1561) comparat cu Evangheliarul lui Radu de la Mănicești 1574. București: Editura Academiei RPR.

\section{ALTE TEXTE}

PC, 1780 = Pravilniceasca condică. A. Rădulescu (ed.) (1957). Pravilniceasca condică București, 1780. București: Editura Academiei RPR.

\section{DICȚIONARE, GRAMATICI ȘI MANUALE}

Alexi, I. (1826). Grammatica Daco-Romana sive Valachica. Viennae: Apud Bibliopolam Josephum Geistinger.

Aristia, C. (1848). Abecedaru françosescu. București: Tipografia lui Eliade.

Clemens, A. (1821a). Kleines Walachisch-Deutsch und Deutsch-Walachisches Wörterbuch. Ofen: Königl. ung. Universitäts-Schriften.

Clemens, A. (1821b). Walachische Sprachlehre. Ofen: Königl. ung. Universitäts-Schriften.

Costinescu, I. (1870). Vocabularu romano-francesu. București: Tipographia Națională Antreprenor C. N. Rădulescu.

DEDR, 1879 = Cihac, A. de (1879). Dictionnaire d'étymologie daco-romane (vol. 2: Eléments slaves, magyars, turcs, grecs-moderne et albanais). Francfort s/M.: Ludolphe St-Goar.

DEM, 1978 = Раевский, Н. \& Габинский, М. (1978). Скурт дикиионар етимоложики ал лимбий молдовенешть. Кишинэу: Редакция Принчипалэ а Енчиклопедией Советиче Молдовенешть.

DER, 2002 = Ciorănescu, A. (2002). Dicționarul etimologic al limbii române (T. Șandru Mehedinți \& M. Popescu Marin, trad.). București: Editura Saeculum I. O. (Originalul publicat în 1954-1966).

DEX, 1998 = Coteanu, I., Seche, L. \& Seche, M. (coord.) (1998). Dicționarul explicativ al limbii române. București: Univers Enciclopedic.

DSL, 1997 = Bidu-Vrănceanu, A., Călăraşu, C., Ionescu-Ruxăndoiu, L., Mancaș, M. \& Pană Dindelegan, G. (coord.) (1997). Dicționar general de științe: Științe ale limbii. București: Editura Ştiinţifică.

DVL, 1650 = Chivu, Gh. (ed.) (2008). Dictionarium Valachico-Latinum. Primul dicționar al limbii române. București: Editura Academiei Române.

Heliade-Rădulescu, I. (1828). Gramatică românească. Guțu Romalo, V. (ed.) (1980). Gramatică românească de Ion Heliade Rădulescu. București: Editura Eminescu. 
Laurian, A.T. \& Massim, J.C. (1871). Dictionariulu limbei romane. București: Noua Typographia a Laboratoriloru Romani.

LB, 1825 = Lesicon Romănescu-Lătinescu-Ungurescu-Nemțescu. (1825). Budae: Typis et Sumtibus Typographiae Regiae Universitatis Hungaricae.

MDA, 2010 = Sala, M. \& Dănăilă, I. (coord.) (2010). Micul dicționar academic (vol. I-II). București: Univers Enciclopedic Gold.

Micu, S. (1780). Elementa linguae daco-romanae sive valachicae. Vindobonae: Typ. Josephi Nob. de Kurzböck. Zdrenghea, M. (ed.) (1980). Elementa linguae daco-romanae sive valachicae. ClujNapoca: Editura Dacia.

Peltechi Caminar, V. (1854). Ențiclopedie ruso-română. Iași.

Pisone, D. (1865). Dictionariu romanesc, latinesc, germanesc și francesc. București: Tipografia Ioanne Weiss.

Pleșoianu, Gh. (1829). Abețedar franțezo-romanesc. București: Libreria lui George Petrovici.

Șăineanu, L. (1929). Dicționar universal al limbei române. București: Editura „Scrisul Românesc”.

Şincai, Gh. (1805). Elementa linguae daco-romanae sive valachicae. Budae: Tipis Regiae Universitatis Pestanae. Zdrenghea, M. (ed.) (1980). Elementa linguae daco-romanae sive valachicae. ClujNapoca: Editura Dacia.

Vaillant, J. A. (1839). Vocabular purtăreț rumânesc-franțozesc și franțozesc-rumânesc. București: Tipografia lui Friderih Valbaut.

Vida, Gh. (1833). Grammatică practică romano-franțozască. Buda: Cu tipariul Crăieștii Universităţi. 